\title{
Uterine and oviducal protein secretion during early pregnancy in the mouse
}

\author{
G. L. Nieder and G. R. Macon \\ Department of Anatomy, Wright State University, Dayton, Ohio 45435, U.S.A.
}

\begin{abstract}
Summary. Changes in the protein composition of the embryo's environment during early development were studied by analysis of proteins synthesized and secreted by oviducal and uterine explants on Days 1-6 of pregnancy. Although secretions from ampullar and isthmic oviduct and uterus contained many proteins in common, each area also produced its own characteristic proteins. In the uterus, changes in the secretion pattern were found during the peri-implantation period, including both increases and decreases in particular proteins which appear to be dependent on the presence of embryos. Embryo-induced effects on uterine secretion began between 09:00 h of Day 4 and 09:00 h of Day 5. Oviducal secretions exhibited many of the embryo-dependent proteins found in the uterus, but the expression of these proteins did not appear to be influenced by the presence of embryos on Day 1 or Day 3. The characteristic pattern of secreted protein expression by each portion of the reproductive tract may reflect the specialization of each area for certain developmental events.
\end{abstract}

\section{Introduction}

The protein composition of tubal and uterine fluids has been examined in numerous studies of mice (Gore-Langton \& Surani, 1976; Aitken, 1977a, b; Fishel, 1979, 1980; Quarmby \& Korach, 1984; Kapur \& Johnson, 1985, 1986), and rats (Surani, 1975, 1977a, b; Shalgi et al., 1977; Takata \& Terayama, 1979; Kuivanen \& DeSombre, 1985; Komm et al., 1986). These investigations have provided clear evidence of synthesis and secretion by the oviduct and uterus of specific proteins which, when added to serum transudate provide a specialized environment for fertilization, embryo development and implantation. The expression of secreted proteins by the uterus and oviduct is controlled in part by ovarian steroids, both during varied physiological states and in response to exogenous hormones. However, because of the different protocols and techniques used in these studies, a detailed documentation of the changes in the protein milieu occurring as the embryo passed along the reproductive tract has been lacking. The study presented here has directly compared the proteins synthesized and secreted by the oviduct and uterus through the pre- and periimplantation period using a sensitive, high-resolution, two-dimensional electrophoresis system.

In addition to modulation by ovarian steroids, studies of the mouse (Nieder et al., 1987) have suggested that signals from the embryo during the initial stages of implantation may control the secretion of certain proteins by the uterus. In these experiments, administration of oestradiol-17 $\beta$ to mice in experimental delayed implantation (i.e. ovariectomized, progesterone maintained) resulted in distinct changes in the two-dimensional electrophoretic pattern of uterine secreted proteins. In addition, the presence of blastocysts in the uterus was correlated with an increase in the secretion of a $40000 M_{\mathrm{r}}$ basic protein. This protein was secreted in minimal amounts by uterine horns not containing embryos, but under identical hormonal conditions. Recognition of pregnancy may even occur earlier than this, as suggested by investigation of the early pregnancy factor 
phenomenon. This research has implicated an 'ovum factor' in the control of expression of immunosuppressive proteins by the ovary and oviduct during the preimplantation phase (Morton et al., 1980; Nancarrow et al., 1981). We have therefore examined changes in the secretory patterns of the oviduct and uterus which may be dependent on the presence of the embryo.

\section{Materials and Methods}

Preparation of animals. Virgin ICR Swiss mice, 6-10 weeks of age, were induced to ovulate with gonadotrophins (Fowler \& Edwards, 1957), then mated with fertile or sterile (vasectomized) males. Mating was confirmed by the presence of a vaginal plug on the following morning, designated Day 1 of pregnancy or pseudopregnancy. Oviducts were obtained for in-vitro labelling of secreted proteins from pregnant and pseudopregnant animals between 09:00 and 12:00 h on Days 1 and 3. To compare fertile and sterile uterine horns, the uterotubal junctions of mated animals were unilaterally ligated on Day 1, thus preventing the transport of embryos to one horn. Uterine tissue from the sterile and fertile horns was obtained for in-vitro labelling between 09:00 and 12:00 h on Days 4, 5 and 6 .

Labelling of secreted proteins from explanted oviducts and uteri. Segments of uterus were cut from fertile horns, containing at least 5 embryos, and from the contralateral sterile horns. These segments were opened by a longitudinal cut to expose the luminal epithelium. Portions of oviducal ampulla and isthmus were dissected out and split longitudinally to expose the luminal epithelium. Oviducts from pregnant mice had to have contained at least 5 fertilized ova or cleavage-stage embryos. Oviducts from pseudopregnant animals usually contained several unfertilized or degenerating ova. Ova, embryos and any remaining cumulus mass were removed from the oviducal tissue before labelling. Oviduct and uterine explants were preincubated for $1 \mathrm{~h}$ in a simple defined medium, BMOC-3 (Brinster, 1971) containing $0.1 \mathrm{mg}$ bovine serum albumin $/ \mathrm{ml}$, under a $5 \% \mathrm{CO}_{2}$ atmosphere at $37^{\circ} \mathrm{C}$ (Nieder et al., 1987). Tissues were then transferred to $50 \mu \mathrm{l}$ of this same medium containing $200 \mu \mathrm{Ci}\left[^{35} \mathrm{~S}\right]$ methionine $/ \mathrm{ml}(\mathrm{sp}$. act. $1100 \mu \mathrm{Ci} / \mathrm{mmol}$ : New England Nuclear, Boston, MA) and incubated for $3 \mathrm{~h}$. After the labelling period, the tissue explants were removed and the remaining medium was centrifuged to remove any cellular material. The resulting oviducal and uterine conditioned media were lyophilized, reconstituted in electrophoresis lysis buffer containing $8 \mathrm{M}$-urea, $4 \%$ Nonidet P-40 and 2\% pH 3.5-9.5 ampholytes (Ampholine, LKB, Gaithersburg, MD), and stored at $-70^{\circ} \mathrm{C}$ until assayed.

Electrophoresis. Conditioned media samples were analysed by two-dimensional electrophoresis (O'Farrell, 1975) with fluorography, under conditions described previously (Nieder et al., 1987). TCA-precipitable ${ }^{35} \mathrm{~S}$ was measured in $3 \mu \mathrm{l}$ aliquants of the samples before electrophoresis and about $35000 \mathrm{c} . \mathrm{p} . \mathrm{m}$. labelled protein were loaded onto each gel. The first dimension was an isoelectric focussing separation in a $3 \cdot 5-9 \cdot 5 \mathrm{pH}$ gradient run for $12000-15000 \mathrm{~V} \cdot \mathrm{h}$. The second dimension was a $10-18 \%$ linear gradient polyacrylamide-SDS slab gel, run at a constant $4 \mathrm{~W}$ per slab. After fixation in $30 \%$ methanol $+7 \%$ acetic acid, the gels were saturated with fluorographic reagent (Amplify, Amersham, Arlington Heights, IL) and dried onto filter paper. Gels were exposed on Kodak XAR-5 X-ray film at $-70^{\circ} \mathrm{C}$ for 7 days. For each experimental group, at least 3 samples from different animals, collected in separate experiments, were analysed. Reported differences in the pattern of protein 'spots' between experimental groups were consistently observed in all samples of those groups.

\section{Results}

\section{Uterine-secreted proteins}

Proteins secreted from uterine explants on Days 4, 5 and 6 of pregnancy were analysed by two-dimensional electrophoresis and any consistently observed differences in the electrophoretic patterns were noted. The pattern of proteins secreted by the fertile uterine horns on Day 4 (Fig. la) consisted of about 20 'spots' representing individual polypeptides or groups of polypeptides with isoelectric variation. Comparisons of uterine and oviducal secretions (see below) identified sets of proteins unique to each region of the reproductive tract. Proteins found in the uterus but not in either area of the oviduct are marked (U) in Fig. 1(a). Secretion patterns from Day-5 and Day-6 fertile horns are shown in Figs 1(b) and 1(c). Most proteins were present to some degree in secretions on Days 4-6, but differences between the groups in the intensity of some protein 'spots' were very apparent and consistently observed. Between Day 4 and Day 5 of pregnancy, an increase in Proteins 1 and 2 was found. Protein 1 corresponded to the $40000 \mathrm{M}_{\mathrm{r}}$ protein detected in the uterus after oestrogen-induced release from delayed implantation, the expression of which appeared to be embryo-dependent (previously designated Protein 20: Nieder et al., 1987). Protein 2 is a pair of acidic polypeptides of about $25000 M_{\mathrm{r}}$. Other consistently observed changes between Day 4 and Day 5 included the decrease in the amounts of Proteins 3-6. By Day 6 of pregnancy, 

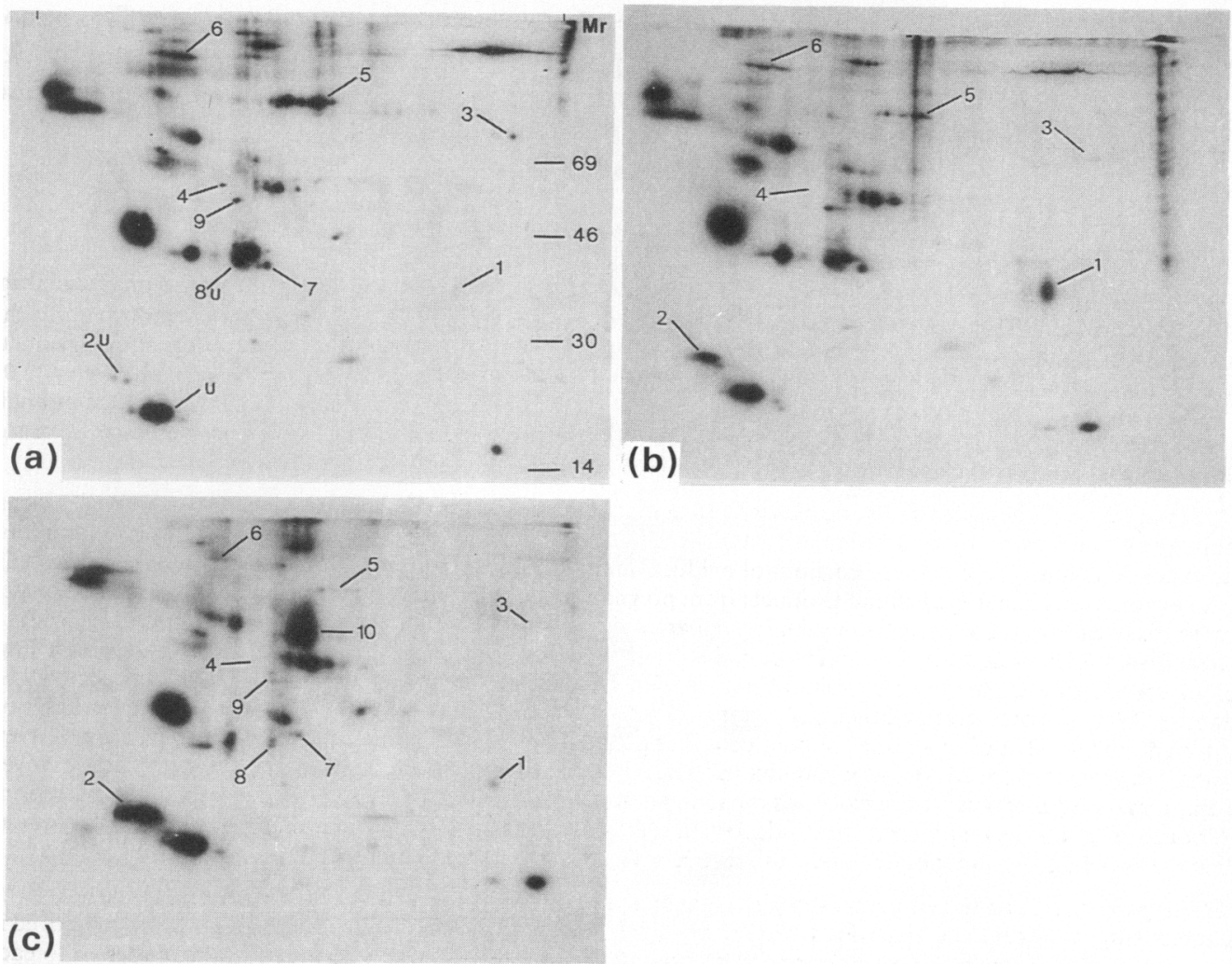

Fig. 1. Two-dimensional electrophoretic pattern of secreted proteins from fertile uterine horns on Day 4 (a), Day 5 (b) and Day 6 (c). Explants of uterus were incubated in vitro with [ ${ }^{35} \mathrm{~S}$ ] methionine and the resulting 'conditioned medium' was prepared for electrophoretic analysis of the labelled proteins. Electrophoresis was carried out as described in 'Materials and Methods', with molecular weight standards $\left(14-69 \times 10^{3}\right)$ run with the second dimension. Proteins found in the uterus, but not in either area of the oviduct, are marked ' $U$ ' in (a). Proteins exhibiting marked changes during the peri-implantation period are numbered and described in 'Results'.

further changes in protein secretion occurred. The amount of Protein 1 decreased to levels similar to those of Day 4. Protein 2, however, showed a further increase over values on Day 5. Proteins which had decreased between Day 4 and Day 5 were further diminished by Day 6, and Proteins 7-9 also decreased between Days 5 and 6. Day-6 uteri also exhibited a pair of diffuse protein 'spots', labelled 10 (Fig. 1c), which were not apparent at earlier times.

To determine whether the expression of Protein 1 and other observed changes between Days 4 and 6 are embryo-dependent, sterile uterine horns on Days 4-6 were analysed. There were no significant differences in the protein patterns of fertile and sterile horns on Day 4 (sterile horn not shown). However, comparisons between contralateral fertile and sterile horns on Day 5 (Figs $1 \mathrm{~b}$ and 2a) showed that, as in the delayed implantation model, the expression of Protein 1 was much greater in horns which contained embryos. The sterile horns also did not exhibit the decreases in Proteins 3-6 between Days 4 and 5 as seen in the fertile horns. Overall, the sterile Day- 5 horn had a secretion pattern very similar to that of the Day- 4 horn. Differences between fertile and sterile horns were also observed on Day 6 (Figs $1 \mathrm{c}$ and $2 \mathrm{~b}$ ) as shown by the higher amounts of Protein 2 in the fertile horn and Protein 4 in the sterile horns. Neither fertile nor sterile Day-6 horns expressed Protein 1 to the extent present in the Day-5 fertile horn. 


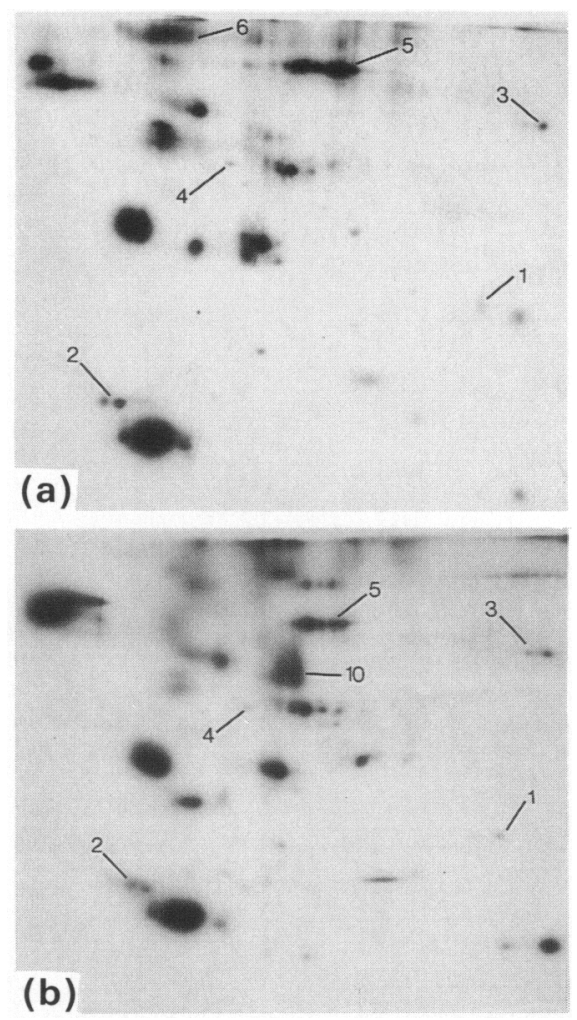

Fig. 2. Pattern of secreted proteins from sterile uterine horns on Days 5 (a) and 6 (b). Changes in Proteins 1 and 3-6 observed in the fertile horns between Day 4 and Day 5 (see Figs la and b) were not found in the sterile horns. Also, differences in the amounts of Proteins 2 and 4 were observed between fertile (see Fig. 1c) and sterile horns on Day 6.

\section{Oviducal-secreted proteins}

Proteins secreted by the ampullar and isthmic portions of the oviduct on Days 1 and 3 of pregnancy and pseudopregnancy were examined. Protein patterns of Day-1 ampulla from pregnant and pseudopregnant animals are shown in Figs 3(a) and (b). The oviduct and uterus secreted many of the same proteins, although some proteins characteristic of each area were also evident. No substantial differences in ampullar secretions from pregnant and pseudopregnant animals were found. Protein 1, the uterine protein whose expression was enhanced by the presence of embryos appeared as a faint 'spot' in the ampullar secretions (labelled 1), but did not appear to be influenced by the presence of the embryo. Uterine Proteins 3, 5, 6 and 9 were also expressed by the ampulla, but again their secretion did not appear to be affected by the presence of the embryo. Secretions from Day-3 ampullar explants were also examined, but did not demonstrate any substantial qualitative differences from the Day 1 pattern. Likewise, no effect of the embryo on Day-3 ampullar secretion patterns could be found.

Figures 4(a) and (b) show the pattern of protein secretion from explants of isthmus on Day 3 of pregnancy and pseudopregnancy. Isthmic secretions were very similar to those of the ampulla, although the two sites could be distinguished by certain characteristic 'spots'. The isthmus also expresses small amounts of uterine Protein 1, but, as with the ampulla, this secretion was not modulated by the embryo. No embryo-dependent changes could be demonstrated by the comparison of isthmic explants from pregnant and pseudopregnant animals. 

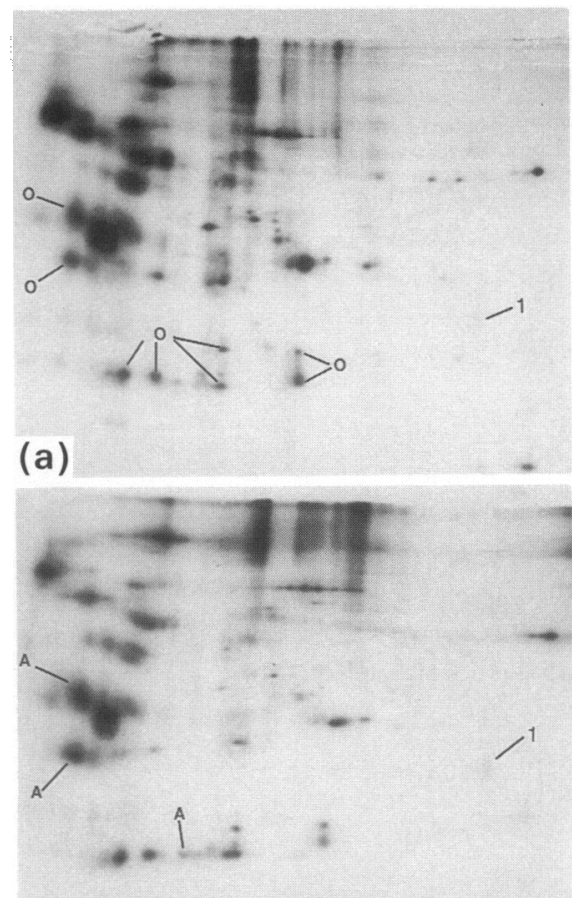

(b)

Fig. 3. Pattern of secreted proteins from the ampullar portion of the oviduct on Day 1 of pregnancy (a) and pseudopregnancy (b). Proteins secreted by the oviduct, but not by the uterus, are labelled ' $O$ ' in (a). Proteins secreted by the ampulla, but not by the isthmus, are labelled ' $A$ ' in (b). No significant differences were observed between ampullar secretions from pregnant and pseudopregnant animals on Days 1 or 3.

\section{Discussion}

As might be expected, secretions from the ampullar and isthmic portions of the oviduct and the uterus have many proteins in common, but in addition contain proteins specific for each region. The functions of these proteins are not known, but it seems reasonable to assume that proteins common to all three portions of the reproductive tract may provide a generally hospitable environment for the developing embryo. Proteins secreted by a particular region may have specific functions in support of the embryo as it traverses that region. It has been shown, for example, that zygotes placed into oviducts maintained in vitro will only develop in the ampulla (Whittingham, 1968). The secretion of certain proteins by the ampulla provides one mechanism by which such functional specialization may be accomplished. Likewise, uterine specific proteins may be functionally correlated to the events of implantation. The absence of certain secreted proteins by the oviduct may therefore, in part, explain the inability of blastocysts, physically prevented from passing to the uterus, to lose the zona pellucida and implant in the normal manner, or to enter embryonic diapause (Orsini \& McLaren, 1967; Weitlauf, 1971).

Differences in the secretion patterns from oviducts of pregnant and pseudopregnant animals or in fertile and sterile uterine horns, would imply an early maternal recognition of pregnancy. Previous study of the uterus during delayed implantation and oestrogen reactivation (Nieder et al., 1987) demonstrated such embryo-dependent secretion early in the initiation of implantation. A $40000 M_{\mathrm{r}}$ basic protein present in minimal quantities during diapause was enhanced within $24 \mathrm{~h}$ 


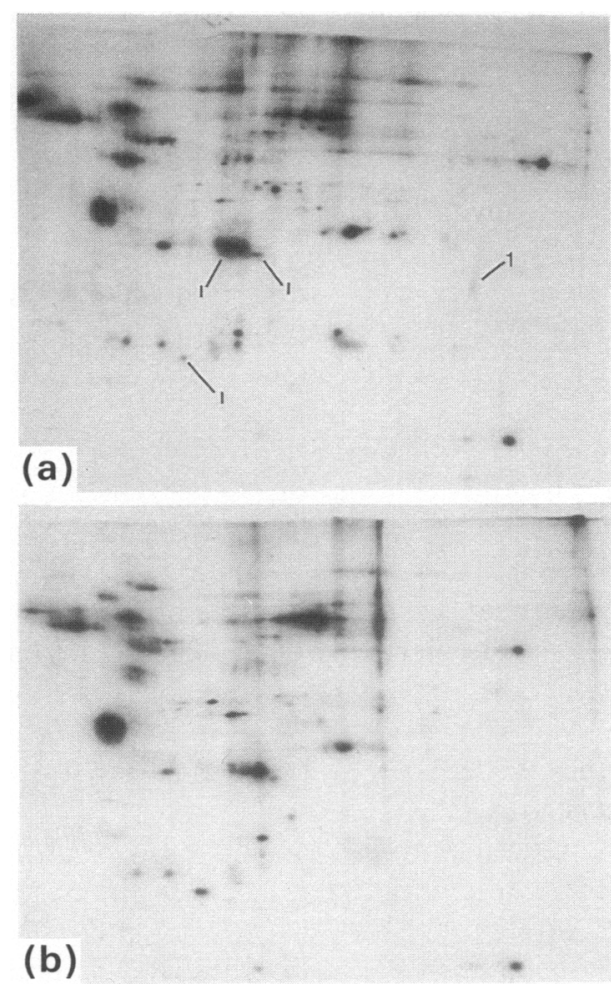

Fig. 4. Pattern of secreted proteins from the isthmic portion of the oviduct on Day 3 of pregnancy (a) and pseudopregnancy (b). Proteins secreted by the isthmus, but not by the ampulla, are labelled ' $I$ ' in (a). No differences in the secreted protein pattern of the isthmus were observed between pregnant and pseudopregnant animals.

after oestrogen administration. The time course of this increased expression during reactivation is similar to the timing of the increase in vascular permeability (pontamine blue reaction) associated with the decidual cell reaction, and with the secretion of a distinct set of proteins by the reactivated blastocyst. The present experiments with 'normal' implantation demonstrate a similarly increased synthesis and secretion of this protein (No. 1) when embryos are present and starting to implant early on Day 5. The increase in expression between 12:00 h on Day 4 and 12:00 h on Day 5 of normal implantation demonstrates a similar correlation of secretion of this protein with the early decidual cell reaction and with the changing secretion pattern of the maturing blastocyst. The transient nature of Protein 1 expression has been demonstrated, since by 12:00 h of Day 6 secretion has decreased to nearly the levels found on Day 4.

These experiments have identified additional changes in uterine secretion which seem to be embryo-dependent. One pair of acidic proteins of $\sim 20000 M_{\mathrm{r}}$ (No. 2) appear to be enhanced in the fertile horns, particularly on Day 6. Other proteins (Nos 3-6) appear greatly diminished in the pregnant horns on Day 5 and 6 . These changes were not noted in the previous study involving delayed implantation, and therefore may be a response dependent on the hormonal programme of normal implantation.

Earlier investigations (Aitken, 1977a, b) reported quantitative, but not qualitative, differences in uterine secretion between pregnant and pseudopregnant animals undergoing either normal or delayed implantation. The different results may be due to the use of one-dimensional electrophoresis and total protein staining in the earlier work, providing limited power to resolve proteins 
synthesized by the uterus. Fishel (1980) compared pregnant and pseudopregnant uteri by analysis of radiolabelled secreted proteins, but only extended the study to Day 4 . The inability to detect substantial qualitative differences between pregnant and pseudopregnant uteri in that study is consistent with the present finding that embryo-dependent changes in uterine secretion are first observed early on Day 5.

In contrast to the uterus, no obvious differences in oviducal secretions were found between pregnant and pseudopregnant animals. The ampulla and isthmus secreted small amounts of Protein 1 on Days 1 and 3 of pregnancy. There was, however, no evidence of modulation of synthesis of this protein by the embryo in either area at any time. Comparisons of other major proteins in the oviducal secretions did not demonstrate any significant differences between the pregnant and pseudopregnant groups. The inability of the cleavage-stage embryo to affect the secretion of proteins by the oviduct may be due either to the lack of an appropriate signal from the embryo at this stage of development, or to the inability of the oviducal epithelium to respond to the embryo in the same manner as the uterus. It should be noted, however, that the failure to demonstrate embryodependent proteins in the oviduct in this study does not imply that an early maternal recognition of pregnancy involving the oviduct does not exist. Reports of the origin of early pregnancy factor (EPF) implicate secretion of low molecular weight $\left(M_{\mathrm{r}} 3000-10500\right)$ proteins from the ovary and oviduct which appear to produce an embryo-dependent immunomodulation during the preimplantation period (Morton et al., 1980; Cavanagh, 1984). If such proteins are produced by the oviduct in response to the embryo, they would have been too small to be resolved in the standard twodimensional electrophoresis system.

In summary, the protein composition in the immediate environment of the embryo changes as the embryo passes through the reproductive tract. Many of the components found in particular regions of the tract appear to be expressed constantly through the preimplantation period, while others appear to be secreted either in response to the hormonal programme of early pregnancy, or as a result of an embryo-derived signal. The relationship of these secreted proteins to other events of early pregnancy are being investigated.

This study supported by grant HD-22368 from the National Institute of Child Health and Human Development.

\section{References}

Aitken, R.J. (1977a) The protein content of mouse uterine flushings during pseudopregnancy. J. Reprod. Fert. 50, 191-192.

Aitken, R.J. (1977b) Changes in the protein content of mouse uterine flushings during normal pregnancy and delayed implantation, and after ovariectomy and oestradiol administration. J. Reprod. Fert. 50, 29-36.

Brinster, R.L. (1971) In vitro culture of the embryo. In Pathways to Conception; The Role of the Cervix and Oviduct in Reproduction, pp. 245-277. Ed. A. I. Sherman. Charles C. Thomas, Springfield.

Cavanagh, A.C. (1984) Production in vitro of mouse early pregnancy factor and purification to homogeneity. $J$. Reprod. Fert. 71, 581-592.

Fishel, S.B. (1979) Analysis of mouse uterine proteins at pro-oestrus, during early pregnancy and after administration of exogenous steroids. J. Reprod. Fert. 55, 91-100.

Fishel, S.B. (1980) Radiolabelled uterine proteins during early pregnancy and pseudopregnancy in mice after unilateral ovariectomy and superovulation. $J$. Reprod. Fert. 59, 473-478.
Fowler, R.E. \& Edwards, R.G. (1957) Induction of superovulation and pregnancy in mature mice by gonadotropins. J. Endocr. 15, 374-384.

Gore-Langton, R.E. \& Surani, M.A.H. (1976) Uterine luminal proteins of mice. J. Reprod. Fert. 46, 27 I-274.

Kapur, R.P. \& Johnson, L.V. (1985) An oviductal fluid glycoprotein associated with ovulated mouse ova and early embryos. Devl Biol. 112, 89-93.

Kapur, R.P. \& Johnson, L.V. (1986) Selective sequestration of an oviductal fluid glycoprotein in the perivitelline space of mouse oocytes and embryos. $J$. exp. Zool. 238, 249-260.

Komm, B.S., Rusling, D.J. \& Lyttle, C.R. (1986) Estrogen regulation of protein synthesis in the immature rat uterus: the analysis of proteins released into the medium during in vitro incubation. Endocrinology 118, 2411-2416.

Kuivanen, P.C. \& DeSombre, E.R. (1985) The effects of sequential administration of $17 \beta$-estradiol on the synthesis and secretion of specific proteins in the immature rat uterus. $J$. Steroid Biochem. 22, 439-451. 
Morton, H., Rolfe, B.E., McNeill, L., Clarke, P., Clarke, F.M. \& Clunie, G.J.A. (1980) Early pregnancy factor: tissues involved in its production in the mouse. $J$. Reprod. Immunol. 2, 73-82.

Nancarrow, C.D., Wallace, A.L.C. \& Grewal, A.S. (1981) The early pregnancy factor of sheep and cattle. $J$. Reprod. Fert., Suppl. 30, 191-199.

Nieder, G.L., Weitlauf, H.M. \& Suda-Hartman, M. (1987) Synthesis and secretion of stage specific proteins by peri-implantation mouse embryos. Biol. Reprod. 36, 687-699.

O'Farrell, P.H. (1975) High resolution two-dimensional electrophoresis of proteins. J. biol. Chem. 250, 4007-4021.

Orsini, M.W. \& McLaren, A. (1967) Loss of the zona pellucida in mice, and the effect of tubal ligation and ovariectomy. J. Reprod. Fert. 13, $485-499$.

Quarmby, V.E. \& Korach, K.S. (1984) Differential regulation of protein synthesis by estradiol in uterine component tissues. Endocrinology 115, 687-697.

Shalgi, R., Kaplan, R. \& Kraicer, P.F. (1977) Proteins of follicular, bursal and ampullar fluids of rats. Biol. Reprod. 17, 333-338.
Surani, M.A.H. (1975) Hormonal regulation of proteins in the uterine secretion of ovariectomized rats and the implications for implantation and embryonic diapause. J. Reprod. Fert. 43, 411-417.

Surani, M.A.H. (1977a) Qualitative and quantitative examination of the proteins of rat uterine luminal fluid during pro-oestrus and pregnancy and comparison with those of serum. J. Reprod. Fert. 50, 281-287.

Surani, M.A.H. (1977b) Radiolabelled rat uterine luminal proteins and their regulation of oestradiol and progesterone. J. Reprod. Fert. 50, 289-296.

Takata, K. \& Terayama, H. (1979) Estrogen-dependent and progesterone-arrested synthesis and secretion of sulfated glycoproteins in luminal epithelia of rat uteri. Biochem. Biophys. Acta 586, 594607.

Weitlauf, H.M. (1971) Protein synthesis by blastocysts in the uteri and oviducts of intact and hypophysectomized mice. J. exp. Zool. 176, 35.40.

Whittingham, D.G. (1968) Development of zygotes in cultured mouse oviducts. i. The effect of varying oviductal conditions. J. exp. Zool. 169, 391-398.

Received 16 March 1987 